\title{
Analysis on Ergonomic Factor of Duties and Organizations towards Stress and Occupational Disease in Manufacturing Industry in Malaysia
}

Mohd Nasir Selamat, Nik Hairi Omar, Rusyda Helma Mohd, Siti Fardaniah Abd Aziz \& Fatin Nur Alia Hamid

To Link this Article: http://dx.doi.org/10.6007/IJARAFMS/v11-i3/10813 DOI:10.6007/IJARAFMS /v11-i3/10813

Received: 21 June 2021, Revised: 24 July 2021, Accepted: 14 August 2021

Published Online: 28 August 2021

In-Text Citation: (Selamat et al., 2021)

To Cite this Article: Selamat, M. N., Omar, N. H., Mohd, R. H., Aziz, S. F. A., \& Hamid, F. N. A. (2021). Analysis on Ergonomic Factor of Duties and Organizations towards Stress and Occupational Disease in Manufacturing Industry in Malaysia. International Journal of Academic Research in Accounting Finance and Management Sciences, 11(3), 177-190.

Copyright: (c) 2021 The Author(s)

Published by Human Resource Management Academic Research Society (www.hrmars.com) This article is published under the Creative Commons Attribution (CC BY 4.0) license. Anyone may reproduce, distribute, translate and create derivative works of this article (for both commercial and non-commercial purposes), subject to full attribution to the original publication and authors. The full terms of this license may be seen at: http://creativecommons.org/licences/by/4.0/legalcode

$$
\text { Vol. 11, No. 3, 2021, Pg. } 177 \text { - } 190
$$

Full Terms \& Conditions of access and use can be found at http://hrmars.com/index.php/pages/detail/publication-ethics 


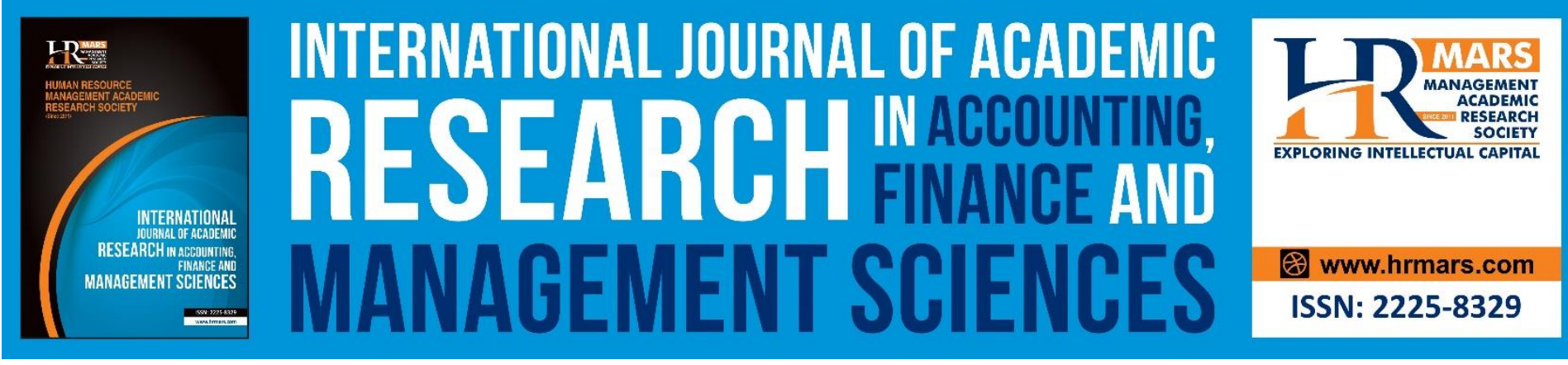

\title{
Analysis on Ergonomic Factor of Duties and Organizations towards Stress and Occupational Disease in Manufacturing Industry in Malaysia
}

\author{
Mohd Nasir Selamat, Nik Hairi Omar, Rusyda Helma Mohd, Siti \\ Fardaniah Abd Aziz \& Fatin Nur Alia Hamid
}

Human Development Program, Centre for Research in Psychology and Human Well-being, Faculty of Social Sciences and Humanities Universiti Kebangsaan Malaysia.

Email: hairi@ukm.edu.my

\begin{abstract}
Stress and occupational disease are the main issues that need to be addressed by the organization. Unconcerned organizations on this issue will provide a negative impact on employees and organizations and contributing to the increase in work accidents, employee absences problems, and the rise in non-infectious diseases at work. Previous studies show that safety and health problems including stress and occupational disease occur mainly in the manufacturing industry. This study will try to seek an answer whether the ergonomic factors of duties and organizations are related to the increase of stress and occupational disease in the manufacturing industry? A total of 843 respondents from few companies and states in Malaysia were reviewed and analysed. The findings of the study indicated that most group workers were unaware of ergonomics-related problems at work place. The research found that there was a significant relationship between the ergonomics factors of organizations and duties with stress and work-related disease in manufacturing industry. Therefore, several initiatives should be taken by the organizations to improve employee performance especially in relation to the implementation of ergonomics aspects and emphasize on safety and health campaign widely.
\end{abstract}

Keywords: Work System, Ergonomics, Occupational Safety Performance, Manufacturing Industry

\section{Introduction}

Based on the statistics declared by the Department of Statistics Malaysia in 2019, the manufacturing sector contributed 4.3\%, the second-highest to Malaysia's economic growth and followed by the agriculture, mining and construction industry. Growth of the manufacturing sector is relatively expanding to a better domestic-oriented market. The effect of the contributions of the sectors involved in Malaysia to the Malaysian economy has successfully recorded the amount of Gross Domestic Product (GDP) continued to increase in the first quarter of 2019 to RM 341.7 billion, the second quarter of 2019, RM 348.8 billion and retain to rise for the third quarter to RM 360.1 billion. 
MANAGEMENT SCIENCES

Vol. 11, No. 3, 2021, E-ISSN: 2225-8329 @ 2021 HRMARS

By an increase in contribution rates to the country's economic development, however, in another perspective, the importance of occupational safety and health aspect should also be given considerable attention. According to the Employment Accident Report by the Social Security Organization (SOCSO) reported the total of work accidents in 2018 is 72,631 cases. This big amount is worrying and the need for immediate action is taken. The following is a comparison of the number of occupational accident cases that happened from 2015 to 2018.

Table 1: Relative Frequency of Accidents Reported, $2014-2018$

\begin{tabular}{|c|c|c|c|c|c|}
\hline Item & 2014 & 2015 & 2016 & 2017 & 2018 \\
\hline Number of accident reported & 63,331 & 62,837 & 66,618 & 69,980 & 72,631 \\
\hline $\begin{array}{l}\text { Number of commuting accident } \\
\text { reported }\end{array}$ & 28,037 & 28,579 & 31,314 & 33,319 & 35,195 \\
\hline Number of industrial accident reported & 35,294 & 34,258 & 35,304 & 36,661 & 37,436 \\
\hline Accident rate (per 10,000 employees) & 102 & 99 & 101 & 103 & 103 \\
\hline $\begin{array}{l}\text { Commuting accident rate (per } 10,000 \\
\text { employees) }\end{array}$ & 45 & 45 & 47 & 49 & 50 \\
\hline $\begin{array}{l}\text { Industrial accident rate (per } 10,000 \\
\text { employees) }\end{array}$ & 57 & 54 & 54 & 54 & 53 \\
\hline
\end{tabular}

Table 1 shows the number of work injuries reported in the year 2014 to 2018 where there was a decrease in accident cases in 2015 which is only 494 cases compared to 2014. However, the accident case at workplace reported continued to increase until the year 2018 and the rate of increase cases is very high. For 2018, the rate reported is 72,631 cases involving 37,915 cases of accidents on the way to or returning from the workplace and 37,436 cases of industrial accidents. The number is expected to continue to rise in the year 2019 if drastic precautions are not taken.

Table 2: Number of occupational accidents in manufacturing sector in 2016 to 2019

\begin{tabular}{ll}
\hline Year & $\begin{array}{l}\text { Number occupational accidents in } \\
\text { manufacturing sector }\end{array}$ \\
\hline $\mathbf{2 0 1 6}$ & 2,315 \\
$\mathbf{2 0 1 7}$ & 1,691 \\
$\mathbf{2 0 1 8}$ & 3,228 \\
$\mathbf{2 0 1 9}$ & 4,070 \\
\hline
\end{tabular}

Source: Department of Occupational Safety and Health, Ministry of Human Resources

Table 2 shows the number of occupational accidents in the manufacturing sector from 2016 until 2019. It is clearly shown in Table 2 where the manufacturing sector is the highest risk industrial sector recorded accident cases. Based on the information obtained from the Department of Occupational Safety and Health, the Ministry of Human Resources, there is a decline in accident cases at workplace in the year 2017 of 1,691 cases compared with 2,315 cases in 2016. The accident cases at workplace increase dramatically from 2018 to 2019, in 2018, 3,228 cases were recorded and 4,070 cases in 2019 and the impacts can be noticed when the worker productivity will decrease and the profit of the company will be affected. 
MANAGEMENT SCIENCES

Vol. 11, No. 3, 2021, E-ISSN: 2225-8329 @ 2021 HRMARS

Besides that, records also show that 59 workers were killed by accident at work. Meanwhile, 182 workers suffered permanent disability and 3829 workers experienced temporary disability.

Safety at workplace is an important aspect in ensuring worker health when performing duties (Selamat \& Mukapit, 2018; Selamat et al., 2020; Takala, 1999; WHO, 2010). International Labour Organization (ILO) and World Health Organization (WHO) in 2010 reported that the manufacturing industry recorded the highest record involving accident and destruction of equipment during the production process. Every 15 seconds, a worker involves in death due to an accident or work-related disease (WHO, 2010).

Statistics from the Department of Occupational Safety and Health, Ministry of Human Resources regarding the investigation of the disease and occupational poisoning issue stated that 1,785 cases were reported until February 2019. Total investigation of disease and occupational poisoning reported 7,258 cases in 2018. Based on the number of cases mentioned for 2019, 537 cases were confirmed as occupational disease by the Department of Occupational Safety and Health. However, statistics for the investigation by the state for 2019 indicated the state of Penang recorded the highest number of cases, 481 reported cases and 9 cases confirmed as occupational disease. Meanwhile, the state of Perak recorded 230 cases which is the second highest number of cases reported and 170 cases verified as occupational disease and followed by the state of Selangor which recorded a total case of 109 cases and 33 cases confirmed as occupational disease.

Various factors are identified that causes the problem of occupational health and safety especially those involving aspects of stress and occupational disease. The research found that the ergonomic aspect was among identified as likely contributing to the problem (Nur-Azreen \& Selamat, 2020; Azman \& Selamat, 2019; Fatin \& Selamat, 2020). Therefore, the introduction of ergonomics is crucial for companies and factories involved in the production and manufacture of products and goods. Ergonomic means interaction between humans and surroundings that involved work safety and health features (Selamat \& Mukapit, 2018). Improved performance is able to take place when there is an interaction between humans and the surrounding. Therefore, this article aims to identify the relationship between ergonomics factors of duties and organizations towards stress and occupational disease in the manufacturing sector in Malaysia. The research applied empirical data and was based on the work system and balancing theory developed by Smith and Carayon (1989). This theory suggests that comprehensive working system aspect provide an impact on the performance of worker and organizations.

\section{Literature Review}

To achieve the main goals of the organization, the perfect aspect of safety and health and work systems should be established in order to implement the organization's goal to cause all the employees and organizations to be safe at work. The uniqueness of the work system and management in the manufacturing sector requires accuracy and details on ergonomic aspects and occupational health and safety to perform all the activities involved. This is because the abandonment of the aspects of occupational health and safety will have a negative impact on the employees and organizations for a long period of time. Moreover, irresponsibility on the aspect of occupational safety and health can affect employees and organizations and outsiders that are involved with the organization's activities. According to Hagg' (2000) and Bridger (2003), the ergonomic environment of workstation literally giving an impact on human resources either psychologically or physiologically. This physiological and 
MANAGEMENT SCIENCES

Vol. 11, No. 3, 2021, E-ISSN: 2225-8329 ๔ 2021 HRMARS

psychological problem will increase the stress level and affect the organization's productivity (Selamat, 2013).

Besides that, other studies show that if occupational safety and health are not given enough attention, there will be an increase in the problem of occupational disease, work stress, get involved in accidents (minor and major), the problem of workload which will affect work performance (Mahboobi, Taghipour \& Ali, 2020; Syamil \& Selamat, 2020; Selamat, 2016; Zakaria et al., 2012). Therefore, an ergonomic work system approach is to be able to help improve work performance by making individual work systems more productive and efficient (Mahmud et al., 2015; Selamat, 2016; Shaliza et al., 2009; Zafir, 2009). However, the ergonomic involvement is not implemented by employers on the organization and employees and this has led to problems involving the aspect of worker safety and health. One of the main factors of safety failure is an organization itself, this shows that organizations play an important role in the performance of employees' health and safety.

Employee performance is a measure based on the work that is in line with the performance that needs to be achieved (Sabine \& Micheal, 2002). Therefore, among the efforts that employers can do in improving the performance of employees at workplace are to fulfil the support needs and maintain maximum levels of physical, mental and social wellbeing in all aspects at work (Archer et al., 2009). The focus on occupational safety and health is limited that causes some occupational problems to occur in the organizations mainly in the manufacturing sectors such as occupational accident, occupational disease, work stress and work absence (Kawakami \& Kogi, 2005; Loo, Richardson \& Alam, 2012; Selamat, 2016). Stress and occupational disease are among the problem that should be addressed in the manufacturing industry with the system and nature of the manufacturing industry that owns the uniqueness of their own way of work according to the products and services provided. Therefore, the possibility for employees is exposed to stress problems and has poor health level is high.

As stated by Kagan et al. (1995), work stress refers to the reaction of emotion, mental and behaviour to vulnerabilities that caused by elements in a work environment that is largely unaware by employees. Besides that, the work stress of the worker is also considered as an interaction between individuals and the source of demand within their environment (Colligan \& Higgins, 2005; de-Jong \& Zaweydeh, 2002). Work stress occurs when demand exceeds their capability, while stress related to work is a reaction and or result that occur due to the stress experience itself (Jensen \& MChintos, 2007). Briefly, occupational stress can be defined as the dangerous emotion and physical reaction that occurs when the work requirements are not suitable with capabilities, resources and employee needs (Erdimansyah, 2008; MahmodAlHusaini, 2008; Selamat, 2016).

The definition stated clearly shows the occupational stress is a chronic condition caused by situations at work that can give a negative impact on individual work performance and their well-being. This situation is able to reduce work performance, decrease work satisfaction, increase the risk of absence at work and accident and negatively affect the worker's health (Xiang, 2014; lqbal \& Waseem, 2012). There are many surveys and studies around the world indicating that occupational stress will increase the management cost, organizations and country. As an example, a national survey conducted in the United States by life insurance company found that half of the adult employees considered their jobs stressful (Duane \& Sydney, 2005). Other surveys by North-western National Life show that $40 \%$ of American employees think their work is tough. The estimated disease cost related to 
MANAGEMENT SCIENCES

Vol. 11, No. 3, 2021, E-ISSN: 2225-8329 @ 2021 HRMARS

stress in the US industry reported in the year 1995 was around $\$ 13,000$ for each employee in every profession every year (Bruhn, Chesney \& Salcido, 1995).

Past studies also showed several factors that influence stress at work. This may be through worker's evaluation of adaptation with technology changes in the surroundings or through high stress working environment (Colligan \& Higgins, 2005). Next, five stress categories at work have been identified: (1) unique factor for work, (2) roles in the organization, (3) career development, (4) interpersonal work relations, and (5) organizations structure. Besides that, the workload is considered the main contribution to occupational stress (Ahsan et al., 2009; Al-Aameri, 2003; Salleh et al., 2008; Selamat, 2016; Yahaya et al., 2010). For example, in Malaysia, studies among academics show that the higher the workload, the more work stress (Chan et al., 2000, Ahsan et al., 2009).

Besides that, two main concerns that cause employees to be stressed at work are workloads and work situations (Edwards, 2001; Salleh et al., 2008; Selamat \& Mukapit, 2018). However, Selamat (2016) and Shaliza et al (2009) found that ergonomic aspects such as factors of workstation and work systems have significant relationships with stress and work tension as well as mental health problems that related to work. Indirectly this matter has an impact on the employee health level so it is affected their own performance.

Occupational disease or health level refers to the symptoms shown by an individual, including psychological diseases such as depression, anxiety and all types of physical disorders (Kerstin et al., 2005). In this research, occupational disease is defined as a condition among individuals that causes them to feel sick, reasons of physical aspect, aspect of physiological and psychological. The term occupational disease generally can be exchanged with disease and essentially refers to a bad health condition.

Studies on health and well-being that involve six Asian countries (China, Hong Kong, Indonesia, Malaysia, Singapura, Thailand) discovered that more than $40 \%$ of each country experienced few minor health problems (September 20, 2015). Hong Kong is the highest minor problem with 55\%, while Thailand shows the lowest with $30 \%$ from each respondent. Malaysia shows $48 \%$ of 532 respondents undergo health problems. This indicates that the health problem occurs can be the main concern to balance work of life including physical and emotional fitness.

Physical aspects which refer to the body and mental condition that cause pain, discomfort, or distress to a suffering individual or anyone in contact with the person can be considered as a disease. Sometimes, this term is widely used to include injuries, disability, syndrome, infections, symptoms, deviant behaviour and unusual functions. Various studies have been conducted showing that the impact of poor health levels can be caused by less implementation of ergonomics aspects at work (Fatin \& Selamat, 2020; Kefri \& Selamat, 2021; Selamat, 2016; Shaliza et al., 2009; Zafir, 2009). Similarly, the problem of poor health levels may be due to the lack of attention on occupational health and safety addressed at work (Azman \& Selamat, 2019; Nur-Azreen \& Selamat, 2020).

Theoretically, a matter involving management of ergonomic factors and relation with occupational stress and disease, balance theory has a further explanation. Balance theory was proposed by Carayon and Smith in 1989 to develop a realistic and holistic approach to the work system. This theory also involved an integrated approach in identifying elements involved in the work system. This theory involved work systems, loads and outcomes earned to employees and areas involved. Balance Theory and the Work System Model include five elements namely individual, duties, organizations, environment, and the machine will produce load. The load on individuals can be influenced by physical demand, psychological 
MANAGEMENT SCIENCES

Vol. 11, No. 3, 2021, E-ISSN: 2225-8329 @ 2021 HRMARS

reactions based on individual perceptions. Therefore, to ensure that the load is always balanced, the concept of counterbalance should be applied to replace the excessive negative aspect with a positive aspect. The purpose is to form a balance in the work system. The results of the interaction between the work system and the load will produce various aspects studied in this research. Among the results obtained on employees are work satisfaction, occupational stress and occupational safety and health and work performance. Besides that, results obtained such as creativity and innovation, organization involvement and organization nationality.

In order to create effective aspects of occupational disease and stress management, several factors need to be involved and complement each other, the commitment of the company management itself. Research conducted by Guo et al. (2016) found that four factors of safety and health management failure until caused stress problems and occupational disease to occur are organization factor, less of security control, weak policy and bad employee behaviour. This shows the role of the organization or company will also determine either implementation safety at workplace is successful or otherwise. Therefore, the level of awareness and promotion to implement ergonomic aspects should be done by all levels of workers within the organization.

\section{Methodology}

The paper applied a qualitative method about the factor ergonomic of duties and organizations on stress and occupational disease to collect authentic data from selected respondents. The survey method by using a constructed questionnaire is also applied. Survey Questionnaires aimed to measure the features, experiences, knowledge and opinions of samples and populations. The data obtained involved industries or organizations in the manufacturing sector in several states in Malaysia including Selangor, Negeri Sembilan, Johor, Kedah, Perak, Perlis, Pahang and Kelantan. Employees from different sub-sectors in the manufacturing sector were selected as respondents. This is because this worker is involved in various work activities and has their own technique and task. Activities in this manufacturing sector also involve physical duties including the use of machines that are more exposing to the risk of danger and safety problem.

Table 3: Reliability of Research Instruments

\begin{tabular}{lll}
\hline Dimension & Item Num. & Reliability Value \\
\hline Occupational Disease & 14 & 0.88 \\
Occupational Stress & 14 & 0.88 \\
Duty Dimension & 18 & 0.74 \\
Organization Dimension & 17 & 0.82 \\
\hline
\end{tabular}

Besides that, a set of questionnaires was constructed to determine the element of ergonomic factors of duties and organizations in the manufacturing industry by adapting few past studies. This means that few elements and measuring tools from previous studies were used to help in measuring the research variables. The five-point Likert scale is used to measure each item in the questionnaires.

Those items were translated into the Malay language because it is the national language of Malaysia and for the purpose of ensuring all the respondents understand the items given. The questionnaire was also tested in a pilot study before the actual research was conducted and had a high level of reliability. Based on Table 3, Alpha Cronbach for each 
MANAGEMENT SCIENCES

Vol. 11, No. 3, 2021, E-ISSN: 2225-8329 @ 2021 HRMARS

dimension shows that the majority have high reliability over 0.70 . The data were analysed using Statistical Package for Social Sciences (SPSS) version 25.

\section{Findings and Discussion}

A total of 843 respondents were successfully involved in this research with an estimated period of data collection for less than three months. Based on the background of all respondents are consisted of middle-skill and subordinate employees namely production operator, middle-line and support staff. The majority of employees involved with this research are male worker (57.1\%) who are categorized in the age group of 17 years to 27 years old (37.9\%). Most workers in the manufacturing sector are married (54.1\%), Malays $(80.3 \%)$ and worked in this sector for more or less than 5 years (49.1\%). Meanwhile, employees involved in the research have an education level at the secondary level $(44.4 \%)$. The majority of respondents have also served in less than 5 years (49.1\%) and $30.5 \%$ of respondents have worked within 5 to 10 years. This shows that all respondents have the appropriate background to provide research data conducted.

Table 4: Overall Average Mean of Study Variable

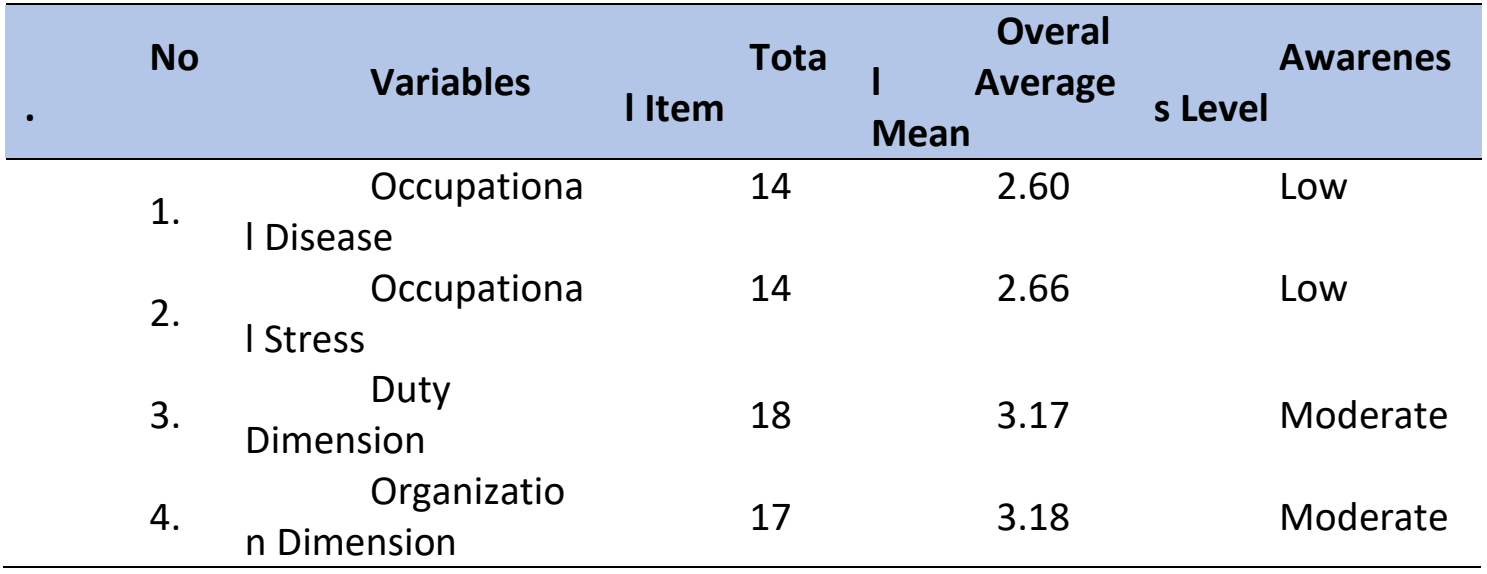

All research variables are also analysed based on the level and tested using the average mean value obtained. There are 14 items in occupational disease and the overall average mean value is 2.60 and the dimension of the stress occupational shows the average mean value of 2.66 with a total of 14 measurement items. This result states that the level of employee awareness towards occupational stress and occupational disease is low.

For duty dimensions containing 18 items, the overall average mean is 3.17 . This explains that the level of employees' awareness of the task is moderate. Meanwhile, for the organization dimensions there are five-sub dimensions in this dimension including basic knowledge indicates the mean value of three items, 3.43. Sub-dimensions of self-involvement and employee support show overall average mean values respectively for three items are 3.32 and 3.55. Next, sub-dimensions of employer support show a 3.21 mean value. This can be concluded that employees' awareness level of basic knowledge, self-involvement, employee and employer support is moderate. Then, sub-dimensions of concern show a 2.66 overall average mean value. These findings revealed the level of employees' awareness is low. Therefore, overall average mean value for organization is 3.18. It shows employees awareness level on the entire organization dimension is moderate. 
MANAGEMENT SCIENCES

Vol. 11, No. 3, 2021, E-ISSN: 2225-8329 @ 2021 HRMARS

Table 5: The correlation findings between ergonomic factor of duty and organizations on occupational disease and stress

\begin{tabular}{|c|c|c|c|c|c|c|}
\hline Variables & $M$ & SD & 1 & 2 & 3 & 4 \\
\hline $\begin{array}{l}\text { 1. Occupational } \\
\text { Disease }\end{array}$ & 36.520 & 8.906 & 0.879 & & & \\
\hline 2. Occupational Stress & 37.322 & 9.123 & $\begin{array}{l}0.812^{*} \\
*\end{array}$ & 0.879 & & \\
\hline 3. Duty Dimension & 57.024 & 8.901 & $\begin{array}{l}0.341 * \\
*\end{array}$ & $\begin{array}{l}0.392 * \\
*\end{array}$ & 0.744 & \\
\hline $\begin{array}{l}\text { 4. Organization } \\
\text { Dimension }\end{array}$ & 55.020 & 9.740 & $\begin{array}{l}0.092 * \\
*\end{array}$ & 0.039 & $\begin{array}{l}0.364 * \\
*\end{array}$ & 0.824 \\
\hline
\end{tabular}

The data were analysed using an inferential approach that was a statistical approach used to make generalizations on a larger group of the population of the study. Correlation tests also were conducted to analyse the relationship between the variables studied. The correlation is a statistical tool used to determine the relationship between two variables. The Pearson Correlation was applied in this research to decide the R-value and significant level which is $P>0.05$.

Table 5 shows that there is a significant relationship between the duty dimensions and the correlation value for the duty dimension is $r=0.341, p=0.000$ where $p<0.05$ and this value indicates the form of relationship is positive. In other perspectives, it shows there is a significant relationship between duty dimension and occupational disease with this degree of correlation relationship is at a moderate level. Next, the findings show there is also a significant relationship between duty dimension and occupational stress with correlation value for duty dimension is $r=0.932, p=0.000$ where $p<0.05$. So, it can be concluded the form of relationship is positive. There is a significant relationship between duty dimension and occupational stress with this degree of correlation relationship is at a moderate level.

The findings are supported by previous studies that clearly show there is a relationship between the variables involved. As an example, excessive work time without taking a break can also cause accidents at work. Long working hours without enough rest can cause chronic fatigue to affect physiological and pathological reactions or can increase the level of depression, insomnia and also loneliness within the individual (Lai et al., 2020; Bartoszek et al., 2020). These fatigues can lead to negligence and a tendency to engage in work accidents (Philip et al., 2016). In fact, countless workload, high levels of stress and long working hours can contribute to poor occupational health and safety performance (Ahsan et al., 2009; Selamat, 2016; Yahaya et al., 2010). Research by Selamat \& Mukapit (2018) found that duty has a significant relationship to accident, disease and stress at workplace. This relationship was also proved by Ahsan et al (2009); Fatin and Selamat (2020), Jia Wern and Selamat (2019); and Zafir et al (2013) that excessive workloads can cause stress at workplace increase. Shaliza et al (2009) also stated that employee stress increases when there is an increase in workload at work. Therefore, it can be concluded based on previous studies that there is a relationship between the duty and performance of occupational safety and health.

Next, for organization dimensions and occupational disease found that there was significant relationship with correlation value for organization dimensions is $r=0.09$ and, $p=0.08$ where $p<0.05$. This shows that this form of relationship is positive. Besides that, referring to the next dimension, there is no significant relationship between organization 
MANAGEMENT SCIENCES

Vol. 11, No. 3, 2021, E-ISSN: 2225-8329 @ 2021 HRMARS

dimension and occupational stress. The correlation value for organization dimension is $r=0.039, p=0.25$ where $p>0.05$. This proves that this form of relationship is positive and there is no significant relationship between the two variables.

According to Suxia et al (2020), the support of organizations on the exposure to safety and health and also ergonomic elements at work has a significant relationship with performance of occupational safety and health and work satisfaction. Besides that, this matter also can be viewed in the research by Gyekye (2005) mentioned that organizations have a significant relationship with the performance of occupational health and safety. Other studies also recorded that work problems on elements of occupational health and safety are due to a lack of attention on ergonomic aspects at work (Kawakami \& Kogi, 2005; Selamat et al., 2020; Selamat \& Mukapit, 2018). This situation causes many occupational diseases that can affect employees. Among them are work stress, work absence, disease and workplace accidents. Stress at work can affect anyone regardless of the aspects of the job. Based on the findings of the study by Selamat (2016), the demand for high quantities of work has shown a major influence on performance of occupational safety and health mainly aspects of stress and health.

Therefore, the interaction between the ergonomic factors of the duty and organization on occupational stress and disease have the relation and relevance as it has been studied by Smith and Carayon (1989; 2000). This is clearly proven that the negligence from the organization to the factor of ergonomic work will cause various problems to exist such as work stress, work absence, disease, and workplace accidents.

\section{Conclusion}

The findings of the correlation test conducted indicated that all variables studied have significant relationships with each other except the dimensions of the organization and occupational stress $(r=0.039, p>0.05)$. This research suggested to the organizations and companies to enhance the level of employee awareness of the ergonomics factors and take initiatives to ensure the employee is not exposed to stress problems at workplace. The organizations need to launch more campaigns and widely regarding the aspect of ergonomic work and occupational safety and health aspects such as safety and health culture workshops for every three-months. Lack of information on ergonomic aspect involving tasks and organizations causes respondents to tend to be vulnerable to work problems. Higher management should play important roles through disseminate related information of safety aspect by good communication approach and openly to receive any report and take an action wisely (Zitty et al., 2019).

Therefore, organizations can apply 'behaviour intervention plan' to the production's employee in implementing behaviour that complies with the 'standard operating procedure'. The purpose of the behaviour intervention plan is to avoid bad behaviour that causes a dangerous accident or the risk of not complying with the procedures and regulations at work. Besides that, health elements can be applied to make employees healthy and able to perform their duty well. Evaluation of duty activities and organization elements need to be addressed and updated in accordance with employee abilities. Avoidance of immoderate work duration and implementation structure ergonomic aspect should be intensified so that more good impact is obtained by employees and the organization. 
MANAGEMENT SCIENCES

Vol. 11 , No. 3, 2021, E-ISSN: 2225-8329 @ 2021 HRMARS

\section{Acknowledgement}

Special thanks to Universiti Kebangsaan Malaysia that supported this research under Young Researcher Encouragement Research Grant (Geran Galakan Penyelidik Muda: GGPM-2017067) and Encouragement Research Grant (Geran Galakan Penyelidikan: GGP-2020-028).

\section{References}

Archer, R., Borthwick, K., \& Tepe-Susanne. (2009). OS\&H a management guide. Engage Learning Australia

Ahsan, N., Abdullah, Z., Gun-Fie, D. Y., \& Shah-Alam, S. (2009). A study of job stress on job satisfaction among university staff in Malaysia: Empirical study. European Journal of Social Sciences, 8(1), 121.

Al-Aameri, A. S. (2003). Source of job stress for nurses in public hospitals. Saudi Medical Journal, 24(11), 1183-1187.

Azman, M. A. A., \& Selamat, M. N. (2019). Sistem kerja ergonomik dan prestasi keselamatan dan kesihatan pekerjaan dalam industri pembuatan. Jurnal Wacana Sarjana, 3(2), 1-1.

Bartoszek, A., Walkowiak, D., Bartoszek, A., \& Kardas, G. (2020). Mental Well-Being (Depression, Loneliness, Insomnia, Daily Life Fatigue) during COVID-19 Related HomeConfinement-A Study from Poland. International Journal of Environmental Research and Public Health, 17(20), 7417.

Bridger, R. S. (2003). Introduction to ergonomics. Taylor \& Francis Group. London and New York.

Bruhn, J., Chesney, A., \& Salcido, R. (1995). Health and organizational issues in managing a multicultural work force. Journal Family and Community Health, 18, 1-8.

Carayon, P. (1989). The Balance Theory and the Work System Model... Twenty years later. INTL. Journal of Human-Computer Interaction, 25(5), 313-327.

Carayon, P., \& Smith, M. J. (2000). Work organization and ergonomics. Applied Ergonomics, 31, 649-662.

Chan, K. B., Lai, G., Ko, Y. C., \& Boey, K. W. (2000). Work stress among six professional groups: The Singapore experience. Social Science Medicine, 50(10), 1415-1432.

Colligan, T. W., \& Higgins, E. M. (2005). Workplace Stress: Etiology and Consequences, Journal of Workplace Behavioral Health, 21(2).

De-Jong, K. J., \& Zawaydeh, B. A. (2002). Comparing stress, lexical focus, and segmental focus: Patterns of variation in Arabic Vowel Duration." Journal of Phonetics, 30, 53-75.

Duane, S., \& Sydney, S. (2005). Psychology \& Work Today. An introduction to industrial and organizational psychology. Pearson Prentice Hall. New Jersey.

Edimansyah. (2008). Assessing and managing risk of occupational stress in male automotive assembly workers in Malaysia. Unpublished doctoral dissertation, Universiti Putra Malaysia.

Edwards, J. R. (2001). Multidimensional construct in organizational behaviour research: An integrative analytical framework. Organizational Research Methods, 4, 144-192.

Fatin N. A. H., \& Selamat, M. N. (2020). Ergonomics work system and occupational safety and health performance in The Manufacturing Sector. The Malaysian Journal of Ergonomics (MJEr), 2(1).

Guo, J. L., Narasimhan, S., Changolkar, L., He, Z., Stieber, A., Zhang, B., Gathagan, R. J., Iba, M., McBride, J. D., Trojanowski, J. Q., \& Lee, V. M. Y. (2016). Unique pathological tau conformers from alzheimer's brains transmit tau pathology in Nontransgenic Mice. Journal of Experimental Medicine, 213(12), 2635-2654. 
MANAGEMENT SCIENCES

Vol. 11, No. 3, 2021, E-ISSN: 2225-8329 ๔ 2021 HRMARS

Gyekye. (2005). Workers' perceptions of workplace safety and job satisfaction. International Journal of Occupational Safety and Ergonomics, 11(3), 291-302.

Hägg, G. M. (2000). Corporate initiatives in ergonomics. Proceedings of the XIVth Triennial Congress of the International Ergonomics Association and 44th Annual Meeting of the Human Factors and Ergonomics Association, "Ergonomics for the New Millennium", 442-445.

Iqbal, M., \& Waseem, M. A. (2012). Impact of job stress on job satisfaction among air traffic controller of civil aviation authority: An empirical study from Pakistan. International Journal of Human Resource Studies, 2, 53-69.

International Labour Organization. (2016). Workplace Stress: a collective challenge. IL0, 2013(April 2016), 57.

International Labour Organization [ILO]. (1996). Your health and safety at work; A Collection of Modules. Ergonomic. Geneva Switzerland: ILO.

Jabatan Keselamatan dan Kesihatan Pekerjaan. (2018). Soalan Lazim: Umum. Retrieved 22 Oktober 2018, from http://www.dosh.gov.my/index.php/ms/hubungi-kami/faqs

Jensen, S., \& Mcintosh, J. (2007). Absenteeism in the workplace: Results from Danish sample survey data. Empirical Economic, 32,125-139.

Jia Wern, M. K., \& Selamat, M. N. (2019). Sistem Kerja Ergonomik dan Prestasi Keselamatan dan Kesihatan Pekerjaan dalam Industri Pembuatan di Klang, Selangor. Jurnal Wacana Sarjana, 3(1): 1-14.

Kagan, N. I., Kagan, K., Henya. \& Watson, M. G. (1995). Stress reduction in the workplace: The effectiveness of psycho educational programs. Journal of Counselling Psychology, 42(1), 71-78.

Kawakami, T., \& Kogi, K. (2005). Ergonomics support for local initiative in improving safety and health at work: international labour organization experiences in industrially developing countries. Ergonomics, 48(5), 581-590.

Kefri, M. S. N., \& Selamat, M. N. (2021). Hubungan antara sistem kerja ergonomik dan prestasi keselamatan dan kesihatan pekerjaan (KKP) di Industri Pembuatan. Jurnal Wacana Sarjana, 5(1), 1 - 11.

Kerstin, W., Julia, R. H., Ivan, R., James, P. B., \& Richard, E. B. (1996). Sickness impact of chronic nonbacterial prostatitis and its correlates. The Journal of Urology, 155(3), 965968.

Lai, J., Ma, S., Wang, Y., Cai, Z., Hu, J., Wei, N., ... Hu, S. (2020). Factors associated with mental health outcomes among health care workers exposed to coronavirus disease 2019. JAMA Network Open, 3, Article e203976.

Laporan Prestasi Ekonomi Malaysia Suku Tahun Ketiga. (2019). Malaysia.

Loo, H. S., Richardson, S., \& Alam, S. (2012). Ergonomics Issues in Malaysia. Journal of Social Science, 8(1): 61-65.

Mahboobi, M., Taghipour, M., \& Ali, A. M. (2020). Assessing ergonomic risk factors using combined data envelopment analysis and conventional methods for an auto parts manufacturer. Work, (Preprint), 1-16.

Mahmud, N., Kenny, D. T., Md-Zein, R., \& Hassan, S. N. (2015). The effects of office ergonomic training on musculoskeletal complaints, sickness absence, and psychological well-Being - A cluster randomized control trial. Asia Pacific Journal Public Health, 27 (2). 1652-1668.

Niu, S. (2010). Ergonomics and occupational safety and health : An ILO perspective. Applied Ergonomics, 41, 744 - 753. 
MANAGEMENT SCIENCES

Vol. 11, No. 3, 2021, E-ISSN: 2225-8329 ๔ 2021 HRMARS

Nur-Azreen, R., \& Selamat, M. N. (2020). Sistem kerja ergonomik prestasi

keselamatan dan kesihatan pekerjaan di industri pembuatan Malaysia. Jurnal Wacana Sarjana, 1-10.

Pertubuhan Keselamatan Sosial (PERKESO). (2018). Laporan Tahunan. Retrieved 2 January 2020, from https://www.perkeso.gov.my/index.php/ms/ laporan/laporanTahunan.

Philip, T., Sophie, A., Göran, K., Debby, G. J. B. \& Constanze, L. (2016). Work time control, sleep \& accident risk: A prospective cohort study, Chronobiology International, 33 (6), 619-629,

Sabine, S., \& Michael, F. (2002). Performance concepts and performance theory, In edited by Sabine, S. (Ed), Psychological management of individual performance, (325). John Wiley \& Sons, New York.

Salleh, A. L., Abu-Bakar, R., \& Keong, W. K. (2008). How detrimental is job stress?: A case study of executives in the Malaysian furniture industry. International Review of Business Research Papers, 4(5), 64-73.

Selamat, M. N. (2016). Ergonomic work system and occupational safety and health performance: Mediating effect of psychosocial work factor. Ph.D Thesis, Malaysia Universiti Sains Malaysia. Penang.

Selamat, M. N. (2013). The determinant of OSH performance: A study on ergonomic work system. Journal Occupational Environmental Medicine, 70.

Selamat, M. N., \& Mukapit, M. (2018). The relationship between task factors and Occupational Safety and Health (OSH) performance in the printing industry. Akademika, 88(3), 65-76. ISI ESCI Indexed.

Selamat, M. N., Mukapit, M., Aziz, S. F. A., \& Zafir, K. M. M. (2019). Re-definition of occupational safety and health performance in Malaysian Manufacturing Industry. International Journal of Recent Technology and Engineering (IJRTE) ISSN: 2277-3878, 8, 2S10.

Selamat, M. N., Akhir, N. M., Abdul Aziz, S. F., Jaaffar, A. H., \& Baker, R. (2020). Reliable dimensions of ergonomic work system in the Malaysian Manufacturing Industries. International Journal of Academic Research in Economics \& Management Sciences, 9(2), 102-112.

Shaliza, A. M., Shahrul, K., Zalinda, O., \& Mohzani, M. (2009). The effect of ergonomics applications in work system on mental health of visual display terminal workers. European Journal of Scientific Research, 31(3), 341-354.

Smith, M. J. \& Carayon, P. S. (2000). Work organization and ergonomics. Applied Ergonomics, 31, 649-662.

Smith, M. J., \& Carayon, P.S. (1989). A balance theory of job design for stress reduction. International Journal of Industrial Ergonomics, 4(1), 67-79.

Suxia, L., Xu, Y., \& Qiang, M. (2020). The effect of perceived organizational support for safety and organizational commitment on employee safety behavior: a meta-analysis, International Journal of Occupational Safety and Ergonomics. DOI:10.1080/10803548.2019.1694778

Syahmil, M. N., \& Selamat, M. N. (2020). Hubungan antara sistem kerja ergonomik dan prestasi keselamatan dan kesihatan pekerjaan. Jurnal Wacana Sarjana, 4(1), 1-13.

Takala, J. (1999). Global estimates of fatal occupational accidents. Fatal Occupational Accidents, 640-646.

WHO. (1998). The World Health Report. Life in the 21st Century, A Vision for All. 
WHO. (2010). Progress on the Health-Related Millennium Development Goals.

Xiang, H., Coleman, S., Johannsson, M., \& Bates, R. (2014). Workplace stress and job satisfaction among biologics development professionals, Health, 6, 1790-1802.

Yahaya, A., Yahaya, N., Amat, F., Bon, A. T., \& Zakariya, Z. (2010). The effect of various modes of occupational stress, job satisfaction, intention to leave and absenteeism companies commission of Malaysia. Australian Journal of Basic and Applied Sciences.

Zafir, M. M. (2009). Persepsi organisasi multinasional di Malaysia terhadap pengurusan stesen kerja ergonomik. Journal of Social Sciences and Humanities, 4(1), 137-146.

Zafir, M. M., Nor-Liza, A., \& Zizah, C. S. (2013). Ergonomics and stress at workplace: engineering contributions to social sciences. Jurnal Pengurusan, 37, 125-131.

Zakaria, N. H., Mansor, N., \& Zalinawati, A. (2012). Workplace accident in malaysia: most common causes and solutions. Business and Management Review, 2(5), 75-88.

Zitty, S. I., Kadir, A., Mazhani, M., \& Mohammad, L. J. (2019). Analisis keberkesanan komunikasi dalam meningkatkan keselamatan dan kesihatan pekerjaan di universiti penyelidikan di Malaysia. Akademika, 89(3), 183-194. 